\title{
Bella Abzug, Queer Rights, and Disrupting the Status Quo
}

\author{
Trevor G. Gates \\ College at Brockport, State University of New York \\ Margery C. Saunders \\ College at Brockport, State University of New York
}

\begin{abstract}
Workers who are lesbian, gay, bisexual, transgender, and queer (LGBTQ)-identified have always been a part of the workplace in the United States, yet there has been a lack of awareness about how to advocate for the needs of these people. This lack of awareness was challenged by Congresswoman Bella Abzug. Abzug's campaign for creating an equal working environment for sexual minorities initiated gradual changes in the public discourse concerning workplace and other broad equality measures for these communities. To frame these gradual transformations within a historical context, we use Lewin's force field analysis framework to examine the change efforts of Abzug. Abzug had beginning success in thawing the status quo yet her visions for equality for LGBTQ people have yet to be realized. Using Abzug's social action as an example, this article concludes that allies must continue to challenge societal oppression, power, and privilege and to demand civil rights protections for LGBTQ individuals.
\end{abstract}

Keywords: gender expression, sexual orientation and LGBTQ issues, employment discrimination, human rights

\section{Introduction}

Tolerance for discrimination against lesbian, gay, bisexual, transgender, and queer (LGBTQ) people is gradually changing. Though 16 to $43 \%$ of sexual minorities experience discrimination in the workplace, there are gradual signs indicating that tolerance for discrimination against LGBTQ communities is at an all-time low (Badgett, Lau, Sears, \& Ho, 2007). Over 400 Fortune 500 companies have antidiscrimination policies that are designed to protect sexual minorities, and over half of U.S. states have laws that prohibit workplace discrimination based upon sexual orientation identity (Human Rights Campaign, 2012).

Federal law does not expressly prohibit discrimination against people who identify as LGBTQ in all workplaces or other settings. Marriage is no longer restricted for same-sex couples in the United States; however, the Employment Nondiscrimination Act (ENDA, 2013) has not been successfully passed. In 2014, President Barack Obama signed an executive order prohibiting federal contractors from discriminating based on sexual orientation and gender identity; sexual orientation identity was already a protected category in federal civil service and in the military (White House, 2014). These growing protections are encouraging and illustrate the gradual nature of change.

Protecting the rights of Americans who are LGBTQ has been of interest to social justice allies during the past several decades. Allies are defined as people who are not targets of the particular social 
justice concern themselves yet question dominant cultural norms that make social justice violations possible; they actively work to eliminate systems of power and privilege within society out of a belief that social justice benefits everyone (Edwards, 2006; Gibson, 2014). In 1974, Abzug first introduced a bill in the House of Representatives that would ban discrimination based upon sexual orientation (National Gay and Lesbian Taskforce, 2014). Since then, various other employment protections for workers who are LGBTQ, generally introduced in various forms of ENDA, have been proposed by several politicians and social justice allies (Kovach \& Millspaugh, 1996). Though these protections have not come to pass, they have set the stage for the gradual change in attitudes about LGBTQ communities (Gates, 2015; Gates \& Rodgers, 2014).

Although national employment protections for workers who are LGBTQ in the United States have been, to date, unsuccessful, the possibility of federal protections might have never reached public discourse without the vision of progressive feminists and LGBTQ activists like Abzug (Levine \& Thom, 2007). Abzug positioned herself as an unlikely LGBTQ activist who proposed politically unpopular LGBTQ rights legislation beginning in the 1970s. Her agenda for LGBTQ equality, though ultimately unsuccessful, represented a disruption of the status quo in the United States.

Disrupting the status quo is a necessary step in affecting change. Using Kurt Lewin's (1947) model of change as a framework, this paper examines Abzug's story, particularly her background and beginnings as a queer activist, her actions that incorporated queer advocacy into the public agenda, and her vision, which has the potential to change employment and other forms of discrimination against American workers who are LGBTQ. To better understand Abzug's contributions to LGBTQ equality, a review of the literature, including academic journal articles, books, and periodicals from 1970 to 2014, was done to identify narratives about her political contributions (Abzug, 1972, 1976, 1990; Aiken, 1974, 1975; "Bella," 1970; Clendinen \& Nagourney, 1999; Cole, 1999; Ertel, 1999; Feldblum, 2000; Fetner, 2008; Gallo, 2006; Leitsch, 1999; Levine \& Thom, 2007; Monifa, 1998; Ogren, 1972; Potter, 2012; "Rights Struggles Shifts to Capitol Hill," 1974; Rodgers, 1998; Russo, 1975; Schultz, 2001; Steinem, 1996). This article reviews Abzug's contributions to LGBTQ equality and explores the impact her work had on disrupting the status quo.

\section{Conceptual Framework}

Disruption of the status quo and broad systemic change occurs gradually. Social psychologist Kurt Lewin, a pioneer of modern social psychology, developed the force field analysis model (Burnes, 2004). The force field analysis model is a framework for helping agents "diagnose forces that drive and restrain” proposed systemic change (McShane \& Von Glinow, 2008, p. 488). Change occurs through a disruption of the status quo or the perspectives commonly held by those in control (Lewin, 1947, 1951).

According to Lewin's (1947) force field analysis model, change occurs through a three-step process: unfreezing, moving, and refreezing. Step 1, unfreezing (or thawing), disrupts the equilibrium and challenges the status quo. Step 2, moving, targets the restraining forces that are invested in the status quo and strengthens the capacities of the driving forces that are advocating change. During this phase, driving forces develop a case for the urgency of change (McShane \& Von Glinow, 2008). Change agents persuade others that the status quo is no longer beneficial and change is necessary. Finally, Step 3, refreezing, occurs when the system aligns with the new, desired behaviors.

Refreezing is necessary to maintain the new methods of conducting business, enable the system to reach a new state of quasistationary equilibrium and prevent the system from regressing (Burnes, 2004; Lewin, 1947, 1951). 
The force field analysis three-step model of change-unfreezing, moving, and refreezing-provides a useful framework for understanding the changes for which Abzug was an advocate. This model will be used to examine her work as a politician and activist during the 1970s and to assert that Abzug herself was a major force for political change and that her political efforts were part of the unfreezing process that has allowed for the many social and political changes toward LGBTQ equality.

\section{Queer Beginnings}

To garner an understanding of who Abzug was and how she positioned herself as a gay rights activist in 1974, her early personal history is examined in this section. Abzug has been described, by herself and others, as a feminist practically from the cradle, a person born with a world consciousness, and a lifelong advocate for the women's liberation movement (Steinem, 1996). Feminism (Sisneros, Stakeman, Joyner, \& Schmitz, 2008) is based upon

(a) A belief that women all over the world face some form of oppression or exploitation, (b) a commitment to uncover and understand what causes and sustains oppression, and (c) a commitment to work individually and collectively in everyday life to end all forms of oppression, whether based on gender, class, race, or culture. (p. 61)

For Abzug, being a feminist was "as natural as breathing, feeling, and thinking" (Shepherd et al., 1997, p. 42).

Born to Russian-Jewish immigrant parents Emanuel and Esther Savitsky in New York City, New York, on July 24, 1920, Bella Savitsky was an outspoken and academically gifted child who saw herself as a tomboy (Abzug, 1976; Ertel, 1999). By preadolescence, she was handing out pamphlets and giving impromptu speeches against anti-Semitism and the importance of a Jewish homeland (Steinem, 1996). She began to nurture her feminist sensibilities and claim her place as a woman as early as age 13, after her father's death, when she began saying Kaddish in the synagogue, a Jewish ritual that was traditionally restricted to males (Steinem, 1996).

Bella Abzug challenged traditional gender expectations of her time in many ways, and certainly through her keen interest in higher education (Levine \& Thom, 2007). After graduating from high school, she commuted from the Bronx to Hunter College in Manhattan (Styer, 1982). While at Hunter, Abzug was student body president; she fostered her budding activism interests by addressing an assembly with First Lady and women's advocate Eleanor Roosevelt (Ertel, 1999). After Abzug earned her bachelor's degree in 1942, she set her sights on law. Although she was denied admission to Harvard Law School because she was a woman, Abzug was one of the six women out of 120 students admitted to Columbia University Law School. During her time at Columbia, Abzug served as the editor of the Columbia Law Review (Rodgers, 1998). She was also married to stockbroker and novelist Martin Abzug for 42 years (Ertel, 1999). She said that her husband did "everything and anything to make possible what [she] was doing" (Abzug, 1990, p. 94).

Soon after Abzug completed her studies at Columbia in 1947, she passed the New York bar exam and began practicing law, which further challenged traditional gender roles, as a practicing female attorney was rare and unusual; women in court were frequently assumed to be law clerks, not lawyers. During the early days of her legal career, she began her now infamous practice of wearing hats to court, "to let judges know she was a practicing female attorney," not a law clerk (Ertel, 1999, 
p. 1). Over time, Abzug's hats became more outlandish, which matched her outspoken and often brash personality and she became a specialist in labor and civil rights law (Levine \& Thom, 2007).

Abzug's interests in labor and civil rights were consistent with her activist spirit, and she remained a progressive activist throughout her legal career (Levine \& Thom, 2007). Not only did she defend marginalized factions such as so-called witches targeted during the McCarthy-era witch-hunt and African Americans in the southern United States (Ertel, 1999), she was vigorous during the antiwar movement during the 1960s, demonstrating her fierce opposition to the Vietnam War through her organizational efforts with Women Strike for Peace, lobbying Congress for a ban on nuclear testing, and calling for an immediate withdrawal of troops (Rodgers, 1998).

By the late 1960s, Abzug had enjoyed a rewarding career as a lawyer and an activist, but she realized that as a politician, she could make contributions that would produce permanent social and political change. In 1969, her political aspirations were directed toward Washington, DC, and the LGBTQ community suddenly became a more viable constituent group. It should be noted that the "queer" community, often included today in the LGBTQ acronym, was then a less visible group within the LGBTQ communities than lesbian, gay, bisexual, and transgender groups. "Queer," a once pejorative term to describe sexual minorities, is now reclaimed by the communities to describe anyone who falls outside society's norms of sexuality and/or gender (Whisman, 2012).

In Greenwich Village during the predawn hours of Saturday and Sunday, June 28-29, 1969, the first LGBTQ rebellion in U.S. history took place (Leitsch, 1999). Nearly 2,000 people were reported to be demonstrating on the streets after a police raid at the popular LGBTQ bar, Stonewall Inn. Arrests had taken place earlier at the Stonewall Inn, which was the culmination of weeks of police harassment (Leitsch, 1999). These collective riots became known as the "Stonewall Rebellion" and were considered a pivotal point in the modern LGBTQ rights movement. The Stonewall Rebellion is widely seen as the beginning of the LGBTQ movement, and as such, this monumental event can be seen as beginning the process of unfreezing the status quo regarding America's view of this community. Abzug, who lived nearby, became a leading national figure in the effort to bring that rebellion to Congress and continue the thawing process.

\section{Queer Action and Thawing the Status Quo}

During the thawing step, the quasistationary equilibrium of the system is targeted. During this step, problems are identified and the traditional methods of conducting business are challenged (Lewin, 1947). Driving forces attempt to move the community away from the status quo, while restraining forces work to maintain it (Lewin, 1951).

Prior to the Stonewall Rebellion, the LGBTQ community was not, except in rare instances, viewed by lawmakers as a viable political force capable of disrupting the status quo. To be clear, the LGBTQ community was powerful; yet, this power was not acknowledged by most lawmakers, or often by the community. Even LGBTQ communities themselves could not agree on their political agendas.

Sexism divided LGBTQ communities, and the perspectives of early male-dominated activist groups such as the Mattachine Society were often privileged over lesbian activist groups such as the Daughters of Bilitis (Gallo, 2006). Many people who were LGBTQ lived "in the closet," and both invisibility and lack of access to mainstream political power kept the status quo in place.

Bella Abzug was open to helping the LGBTQ community destabilize the status quo and became part of the emerging driving force that challenged the societal oppression, privilege, and power that 
marginalized LGBTQ people. Approximately 18 months after the now infamous Stonewall Rebellion, Abzug announced her candidacy for the U.S. House of Representatives. In her progressive Manhattan district, her charismatic nature attracted the immediate attention of journalists and activists alike. "She rolled up the street like a self-propelled pushcart, her hands pumping those of passersby, her big hat flapping and her voice booming: 'Hi. Hey, I'm Bella, your candidate for Congress"” ("Bella," 1970, p. 28).

Drawing upon her progressive roots, her commitment to social justice advocacy, and her witness to the Stonewall Rebellion in 1969, Abzug openly solicited the votes of the LGBTQ community, particularly gay men, at one of the largest bathhouses in New York City (Ogren, 1972). "She embraced gays with zest and they responded warmly, turning out in large numbers as volunteers and voters" (Gosse, 2005, p. 179). The inclusive term LGBTQ itself had not yet become popular (Schulman, 2013); bisexual, transgender, and queer people were less visible constituents of the "gay and lesbian" community that Abzug courted.

Never before had a politician campaigning for national office openly acknowledged the LGBTQ community as a significant constituency; the community placed its complete faith in Abzug (Levine $\&$ Thom, 2007). In her memoir, she acknowledges the faith that marginalized communities, like the LGBTQ community, had in her as she recounts stories of the communities' pleas for her support: "Bella, you're our only hope ...," "There's nobody else to turn to, Bella. Only you ...," and "Bella, if you don't, who will?" (Abzug, 1972, p. 4). Her visibility within LGBTQ magazines, such as The Advocate, captured the community's hope that its time had finally come and that Abzug would be a part of it: "Bella was part of the dream. She fed it ... Politicians had double-talked us for years and here was this woman coming to us!" (Russo, 1975, p. 13). Her embrace of the LGBTQ community helped build the political forces to advance a thawing of the status quo, as this straight woman who heard their plans was headed to Congress, and this gave the community a greater sense of hope and empowerment. Though many politicians would later begin to court people who identify as LGBTQ as a group of constituents, none did so as openly and with such enthusiasm as Abzug. The bold and radical political energy and vision developed in her own life that she brought to her campaign not only warmed the community, but created more energy for political change, as the community in turn rallied and turned out voters. Her strong and brazen personality, her broad feminism that included concern for many communities, including the LGBTQ community, and lastly, her willingness to speak truth to power, was a major force in creating the energy to move the issue forward.

The LGBTQ community and others placed their hopes and dreams in Abzug, and she won her House seat in 1969. She started the first of three terms in the House in 1970. Unfortunately, during this time, Abzug lacked the political capital to make substantive changes for her constituents in the area of LGBTQ rights, as the cultural and political forces that refused to acknowledge the basic rights of the LGBTQ community were very strong. Abzug did, however, begin to earn her reputation as a progressive congresswoman (Monifa, 1998):

[S] he was noticeable, loud, quotable, liberal, a lawyer, a feminist ... she said, "This woman's place is in the House-the House of Representatives." As I listened with my mother, we both were inspired to raise our sights to loftier goals. (p. 80)

During her time as a junior congresswoman, Abzug made it her policy to introduce an anti-sexdiscrimination statement into any bill she could (Ertel, 1999). She accomplished many important progressive changes while in Congress, including coauthoring and pushing through the Freedom of 
Information Act (1966), the Privacy Act (1974), and the Government in the Sunshine Act (1976). She also showed her boldness by being the Congresswoman to call for President Nixon to be impeached.

Many of her LGBTQ supporters, however, wanted more from her: antidiscrimination measures that would protect them, too. Supporters sought a greater disruption of the status quo that was their oppression, and the slowly growing advocacy groups began to press their congresswoman to take action (Vitulli, 2010). It is hard to know for certain why she waited until her third term to introduce legislation, as the historical record does not show her thoughts regarding timing. It might have indeed been the growing force of the LGBTQ community itself pressing her to keep her word. Or perhaps it was her work on so many major pieces of legislation that kept her from moving forward on this campaign promise to address LGBTQ rights. She might have also recognized how controversial this issue was then and wanted to wait until she had more political capital to spend. Though Abzug heard the cries of the LGBTQ community, another force was the rising of the Christian Right movement that actively opposed LGBTQ equality (Fetner, 2008), and the country seemed to be shifting to conservatism, as the election of President Reagan a few years later would suggest.

Despite these barriers, the march for LGBTQ equality continued to grow. Between Stonewall and the early 1970s, a range of new gay rights organizations emerged. The organizations ranged in their advocacy techniques, from the Gay Liberation Front, patterned after antiwar and Black nationalist organizations; to the Gay Activists Alliance, focused primarily on gay oppression; to the National Gay Task Force, dedicated to reformist and mainstream community objectives (Feldblum, 2000). In 1973, LGBTQ activists rejoiced when "the 20 million homosexuals in the U.S. achieved a sort of instant 'cure' as the American Psychiatric Association removed homosexuality from its list of psychiatric disorders" ("Sick No More," 1999, p. 62). Now was the time for a gay rights bill, though LGBTQ advocacy organizations were hardly at a consensus about how to proceed ("Rights Struggle Shifts to Capitol Hill," 1974).

What had occurred, however, was progress toward thawing the status quo of oppression toward the LGBTQ community. Though Abzug did not directly contribute to the declassification of homosexuality from the American Psychiatric Association's (1968) Diagnostic and Statistical Manual of Mental Disorders, her early activism for LGBTQ issues helped increase awareness of the needs of the LGBTQ community (Ertel, 1999). In many ways, there was evidence of a systemic thawing of some of the core institutions that had not treated LGBTQ individuals as full citizens. A complete thawing of the status quo, however, had not been fully realized.

\section{Queer Vision and Further Unthawing}

In 1974, Bella Abzug, with a fellow congressional colleague, introduced, for the first time in Congressional history, a comprehensive gay rights bill. In collaboration with the National Gay and Lesbian Taskforce (2014), Abzug introduced the Equality Act of 1974, a comprehensive federal bill proposing a ban of discrimination against all women, lesbians, gay men, and all unmarried people in public accommodations, to include housing and employment.

The announcement of the bill came without fanfare and without notice to gay activist organizations. The balance of driving and resisting forces began to shift in favor of resisting forces. Failure to include LGBTQ groups in the conversation angered some gay rights organizations, such as the National Gay Taskforce (Aiken, 1974). Her first gay rights bill ultimately failed-it never passed the House Judiciary Committee, where it was referred for consideration (Feldblum, 2000). Abzug and her supporters unapologetically acknowledged that the bill was unlikely to pass yet insisted that its 
introduction was absolutely necessary to the LGBTQ movement as an educational and symbolic tactic (Clendinen \& Nagourney, 1999). And as The Advocate reported, "[Abzug and her supporters] made it clear they did not expect to become universally popular with all segments of society by sponsoring the bill, but were willing to take the risks involved" (Aiken, 1975, p. 4), for if Abzug was not the congresswoman to introduce the bill, who would be? In 1975, in concert with the National Gay Taskforce and a few more supporters, Abzug proposed The Federal Gay and Lesbian Civil Rights Bill, which would amend the Civil Rights Act of 1964 to include gays and lesbians (Aiken, 1975; Levine \& Thom, 2007; Vaid, 1995).

Although Abzug's efforts toward passing a comprehensive gay rights bill were often frustrated by numerous obstacles and further shifts between driving and opposing forces, she continued to nurture her vision for the LGBTQ equality movement (Potter, 2012). She prided herself as an activist who not only "does things," but also one who works "to create a feeling that something can be done" (Abzug, 1972, p. 5). In 1975, Abzug introduced a second gay rights bill, which was also unsuccessful (Feldblum, 2000). She launched a Senate bid in 1976, but was defeated, much to the disappointment of feminist activists who hailed her as an important feminist leader: "There was and there will only be one Bella" (Schultz, 2001, p. xiii). Although she officially left public office in 1976, she continued her work as an activist, particularly in the women's movement. She remained, throughout her career, a social justice ally for LGBTQ causes (Abzug, 1972):

I've been described as a tough and noisy woman, a prizefighter, a man-hater, you name it. They call me Battling Bella, Mother Courage, and a Jewish mother with more complaints than Portnoy. There are those who say I'm impatient, impetuous, uppity, rude, profane, brash, and overbearing. Whether I'm any of these things, or all of them, you can decide for yourself. But whatever I am ... I am a very serious woman. (p. 3)

Abzug's contributions in raising awareness about LGBTQ equality have continued to manifest themselves throughout the last 3 decades. Although the 1980s and 1990s presented many challenges to the LGBTQ community, particularly the HIV/AIDS epidemic and anti-marriage-equality measures (Lind, 2004), the LGBTQ equality movement has since enjoyed significant gains. For example, several states, including the District of Columbia, have passed legislation that prohibits discrimination based upon sexual orientation (Ekeberg \& Tumber, 2004). Sodomy laws were overturned in a number of states, including the Supreme Court's reversal of Brown v. Hardwick, which stated that an individual is not afforded sexual privacy according to the Constitution. In the landmark decision Lawrence $v$. Texas, the Supreme Court found that consensual intimacy between two adults is protected under due process. The decision was significant because it protected consensual intimacy between adults, regardless of the gender of the two partners, and regardless whether penetration occurred (Chauncey, 2004).

Abzug continued, throughout the 90s, to inspire social justice advocacy within her family. Both of her daughters were involved in advocating for the rights of others through their professional lives (Levine \& Thom, 2007). Eva Abzug was associate director of residential services at Bridge, a social service organization, and administered therapy at Maria Droste Services, and Isobel Abzug was head of a national economic development business and political consultant (Levine \& Thom, 2007). Bella Abzug died in 1998, at age 77, following complications from heart surgery. Her vision for equality for marginalized individuals is revered among activists throughout the world (Ertel, 1999). 
Gates and Saunders, 2015

\section{Discussion and Implications for Advocacy}

Bella Abzug's efforts as a congresswoman and activist are an example of incremental change. While her efforts did not ultimately lead to civil rights protections for individuals who identify as LGBTQ, her work incrementally began to disrupt the status quo. Though LGBTQ activism faced many setbacks during the $80 \mathrm{~s}$ and $90 \mathrm{~s}$, including a shift toward restraining forces and greater conservatism in the United States (Dentato, Orwat, Spira, \& Walker, 2014; Fetner, 2008), the thawing of the status quo continued. Allies continued to demand rights for LGBTQ people.

Nevertheless, while Abzug's efforts did not measurably change the status of LGBTQ civil rights in the United States, she did help continue the unfreezing process that started with the Stonewall Rebellion, and making a political claim at the national level was an accomplishment in and of itself, as she helped make discrimination against the LGBTQ community visible as a national problem; this marked a shift in the political equilibrium of the United States regarding this issue.

Yet LGBTQ communities continue to experience marginalization and discrimination in our society. There are no universal federal employment protections for workers who identify as LGBTQ, and arbitrary and discriminatory employment decisions based upon sexual orientation and gender identity can be made without consequence. In some jurisdictions, despite the Supreme Court ruling on marriage equality in 2015, LGBTQ people are still having their right to legally wed challenged, as well as the right to adopt and/or otherwise establish a family (Brydum \& Ennis, 2015). Until "Don't Ask Don't Tell" was fully repealed in 2011, LGBTQ service members were discharged from the Armed Forces at alarming rates (Gates \& Rodgers, 2014). LGBTQ individuals remain second-class citizens in many places in the United States.

Many see that a major shortcoming of Abzug's approach was that she failed to bring an adequate number of organizations to the table as allies. Gay and lesbian allies often borrow upon the strategies and approaches of both the civil rights and women's rights movements. While Abzug always worked to gain the support of many feminist leaders (Vaid, 1995), less effort was made to garner the support of other prominent civil rights organizations of the time. A great deal could be learned about community mobilization from the African American civil rights movement, yet Abzug failed to support key African American civil rights organizations. This was a grave mistake that might have led to the failure of her proposals to gain needed momentum.

A great deal can also be learned from Abzug's challenges. Her failure to identify prominent African American civil rights organizations as significant stakeholders in LGBTQ equality was a clear mistake. Including important stakeholders would have further strengthened the momentum of the movement and served to bolster driving forces toward LGBTQ civil rights. Future generations of allies can learn from this. Social justice allies who press for community change must identify important stakeholders. Allies are unlikely to be successful in producing change if they ignore or minimize the contributions of those who have paved the way in prior movements.

Social justice allies can learn about the importance of not giving up from Abzug and her advocacy efforts. Too often, we become disenchanted with the lack of change in the United States. Real progress, especially in LGBTQ rights, can sometimes seem far beyond reach and far beyond what is realistically possible. Social justice allies may attempt to advocate for change yet experience failure and give up too soon. Real change for the LGBTQ community seems distant, so the community often focuses on changes that can be made and successes that can be achieved today. Often the adage that is followed among policy change activists is to focus on what is "realistic," and, thus, they may 
attempt only small, incremental changes. Abzug's story is an example of how one person can begin to disrupt the equilibrium of society by advocating for a transformative goal, such as overturning the marginalization of LGBTQ people by both revealing the invisibility of such oppression, and challenging it. To create the unfreezing of the sociopolitical equilibrium, perhaps social justice allies would always do well to be bold and disruptive when groups are being oppressed, as Bella Abzug did when she made an unequivocal claim for equal rights for all LGBTQ individuals.

After these efforts by Abzug, there was a refreezing of the status quo in Congress on LGBTQ issues, mostly due to the rise of Reaganism and the reassertion of so-called traditional values. But despite these forces that tried to maintain the equilibrium of oppression, LGBTQ activists continued to build more social, cultural, and political structures and resources that would help set the stage for the next big push on the national front. Cultural forces begin to shift the dynamics, as TV shows about LGBTQ people like Will and Grace and Queer Eye for the Straight Guy entertained many Americans, and greater acceptance started becoming more common, especially among younger Americans.

LGBTQ issues would not surface in a significant way until the political mood of the country shifted with President Bill Clinton's election (Mertus, 2007). But at that time, incrementalism seemed to be the preferred political strategy, at least on the national level. For example, as the LGBTQ movement gained more power after the visibility and power shown during the Clinton campaign, national groups promoted changing the discriminatory policies in place in the military (Johnson, Rosenstein, Buhrke, \& Haldeman, 2015), as this was strategically seen as a more palatable issue that would create incremental change. This issue did not move the LGBTQ community as much as the equal marriage movement, which erupted in a seemingly spontaneous fashion, without the initial support and approval of some national LGBTQ groups, which cautioned against such a bold goal because they feared that many states would pass constitutional amendments that would take much longer to overturn (Pelts, 2014). But equal marriage was not only an issue that galvanized almost the entire LGBTQ community, it was one that struck at the heart of LGBTQ oppression by focusing on the key heart of the issue; this was about the validity of our relationships. And it had the allure of being about romance and weddings, which appealed to the straight community in a direct and compelling way. It may take not only forceful and charismatic personalities to help lead movements, like Abzug, it may also take a vision that inspires people to come together for social and political change, so that the equilibrium is pushed far enough off balance to create a big enough opening for real change, and movement forward is possible.

There has been much movement on many LGBTQ issues and there are many current opportunities for allies to speak out and to disrupt the status quo in society that continues to treat LGBTQ individuals as less than full citizens. On a positive note, because of the recent Supreme Court decision that found same-sex marriage bans to be unconstitutional, the government can no longer discriminate against same-sex couples (Freedom to Marry, 2015). However, ENDA has still not become law; and in some states, LGBTQ employees can be fired from their jobs solely because of their sexual orientation and/or gender identity (Gates \& Rodgers, 2014; Rudin, 2012). Allies for social justice must continue to challenge laws that treat LGBTQ people as second-class citizens. The privileging of heterosexual identities over all others must be disrupted.

It is precisely for this reason that Abzug is most remembered. Abzug was disruptive of the systems of power and privilege that dominated her time. Her work for real LGBTQ equality and other politically unpopular issues of her time are remembered because she had the vision to look beyond what is possible at the time to what may be possible later. In a book of stories about important women of our time, Schultz (2001) notes that "Abzug established a standard of integrity and 
chutzpah (nerve, courage) that challenges us all to tell the truth and to fight back. There was and there will only be one Bella" (p. xiii). There was only one Bella Abzug, but there can be many others social justice allies who have a vision for a better future and actively work toward that future by thawing the status quo.

\section{Summary}

The story of Abzug illustrates not only that gradual and incremental change in resolving the problem of LGBTQ prejudice and discrimination is a historical reality, as it is for most movements, but that also bold visions and values are needed to unfreeze the status quo and foment movement forward. There is a need for an integrated and transformative politics that will create and jumpstart political movements for needed changes, especially on the economic front. Once basic civil and political human rights are secured for all LGBTQ individuals, then the movement must continue to be bold and address deeper inequalities that affect the most vulnerable of the LGBTQ community, and the LGBTQ movement must identify issues to not only remain relevant, but also to keep the broader momentum toward advancing human rights for all. This is another way to create allies for the future, and it is time for LGBTQ communities to give back to the other communities that have supported the movement, and in which many LGBTQ people live. Some national LGBTQ organizations seem to be doing this more now, as actions taken for LGBTQ immigrants, and homeless youth, are engendering cross class and ethnic collaboration. Nothing would make Bella Abzug prouder that to see the movement she helped advance become more integrated with organizations and movements representing the interests of women, youth, older adults, the poor, communities of color, and other oppressed groups.

In the United States, there are many current opportunities for social justice allies in the LGBTQ rights movement to advocate for equality, employment protections, and other civil rights measures, disrupting the current system of power and privilege that discounts the lives of LGBTQ people. Social justice allies must organize their communities to speak out against businesses that treat LGBTQ people as less than equal. If necessary to make change, boycotts of such businesses should occur. Social justice allies have an important role in demanding change for the LGBTQ community and all communities, even when such change is socially or politically unpopular. Allies must continue to be a part of the driving forces that destabilizing the status quo that accepts the marginalization of the LGBTQ community. Allies should also endeavor to work across communities, countries and issues to craft a social justice agenda for a more just, sustainable world. Like Abzug, we all must be bold to change society. 
Gates and Saunders, 2015

\section{References}

Abzug, B. (1972). Bella!: Ms. Abzug goes to Washington (M. Ziegler, Ed.). New York, NY: Saturday Review Press.

Abzug, B. (1976, February). Womanpower: A new American doctrine. Redbook, 146, 34-38

Abzug, B. (1990). Martin, what should I do now? Ms., July/August, 94-96.

Aiken, D. L. (1974, August 14). Suddenly, the mood changes. The Advocate, 144, 1-9.

Aiken, D. L. (1975, April 23). Bella's bill: "Time to enjoy the fruits." The Advocate, 162, 4.

American Psychiatric Association. (1968). Diagnostic and statistical manual of mental disorders (2nd ed.). Washington, DC: Author.

Badgett, M. V. L., Lau, H., Sears, B., \& Ho, D. (2007). Bias in the workplace: Consistent evidence of sexual orientation and gender identity discrimination. Los Angeles, CA: The Williams Institute.

Bella. (1970, October 5). Newsweek, 76, 28-29.

Brydum, S., \& Ennis, D. (2015, October 22). Kim Davis: "Soldier for Christ" whose "battle has just begun." The Advocate. Retrieved from http://www.advocate.com/marriageequality/2015/10/22/kim-davis-soldier-christ-whose-battle-has-just-begun

Burnes, B. (2004). Kurt Lewin and the planned approach to change: A re-appraisal. Journal of Management Studies, 41, 977-1002. doi:10.1111/j.1467-6486.2004.00463.x

Chauncey, G. (2004). What gay studies taught the court: The historians' amicus brief in Lawrence v. Texas. GLQ: A Journal of Lesbian and Gay Studies, 10, 509-538. doi:10.1215/10642684-10$3-509$

Clendinen, D., \& Nagourney, A. (1999). Out for good: The struggle to build a gay rights movement in America. New York, NY: Simon \& Schuster.

Cole, R. (1999). Get 'em in, throw 'em out: Military policies on gays make no sense. In C. Bull (Ed.), Witness to revolution: The Advocate reports on gay and lesbian politics, 1967-1999 (pp. 2732). Los Angeles, CA: Alyson Books.

Dentato, M. P., Orwat, J., Spira, M., \& Walker, B. (2014). Examining cohort differences and resilience among the aging LGBT community: Implications for education and practice among an expansively diverse population. Journal of Human Behavior in the Social Environment, 24, 316-328. doi:10.1080/10911359.2013.831009

Edwards, K. E. (2006). Aspiring social justice ally identity development: A conceptual model. Journal of Student Affairs Research and Practice, 43, 1235-1256. doi:10.2202/19496605.1722

Ekeberg, E., \& Tumber, R. (2004). Sexuality and transgender identity issues in employment. Georgetown Journal of Gender and the Law, 5, 387-406.

Employment Nondiscrimination Act (ENDA) of 2013, S. 815, 113th Cong. (2013). Retrieved from https://www.congress.gov/bill/113th-congress/senate-bill/815/text

Ertel, M. L. (1999). Bella Abzug (1920-1998). In J. Scanlon (Ed.), Significant contemporary American feminists: A biographical sourcebook (pp. 1-7). Westport, CT: Greenwood. 
Feldblum, C. R. (2000). The federal gay rights bill: From Bella to ENDA. In J. D'Emilio, W. B. Turner, \& U. Vaid (Eds.), Creating change: Sexuality, public policy, and civil rights (pp. 149187). New York, NY: Saint Martin's Press.

Fetner, T. (2008). How the religious right shaped lesbian and gay activism. Minneapolis, MN: University of Minnesota Press.

Freedom of Information Act of 1966, 5 U.S.C., 89th Cong. (1966). Retrieved from http://www.gsa.gov/portal/content/105305

Freedom to Marry. (2015). The Defense of Marriage Act. Retrieved from http://www.freedomtomarry.org/states/entry/c/doma

Gallo, M. (2006). Different daughters: A history of the Daughters of Bilitis and the rise of the lesbian rights movement. New York, NY: Seal.

Gates, T. G. (2015). Overcoming discrimination against LGBTQI employees. Journal of Employee Assistance, 45, 24-26.

Gates, T. G., \& Rodgers, C. G. (2014). Repeal of Don't Ask Don't Tell as a "policy window”: A case for the passage of the Employment Nondiscrimination Act. Journal of Discrimination and the Law, 14, 5-18. doi:10.1177/1358229113500419

Gibson, P. A. (2014). Extending the ally model of social justice to social work pedagogy. Journal of Teaching in Social Work, 34, 199-214. doi:10.1080/08841233.2014.890691

Gosse, V. (2005). Rethinking the new left: An interpretative history. New York, NY: Palgrave Macmillan.

Government in the Sunshine Act, H.R. 11656, 94th Cong. (1976). Retrieved from https://www.congress.gov/bill/94th-congress/house-bill/11656

Human Rights Campaign. (2012). State employment laws and policies. Retrieved from http://www.hrc.org/files/assets/resources/Employment_Laws_and_Policies.pdf

Johnson, W. B., Rosenstein, J. E., Buhrke, R. A., \& Haldeman, D. C. (2015). After “Don’t Ask Don’t Tell": Competent care of lesbian, gay and bisexual military personnel during the DoD policy transition. Professional Psychology: Research and Practice, 46, 107-115. doi:10.1037/a0033051

Kovach, K., \& Millspaugh, P. (1996). Employment Nondiscrimination Act: On the cutting edge of public policy. Business Horizons, 39, 65-74. doi:10.1016/S0007-6813(96)90054-3

Leitsch, D. (1999). Police raid on N.Y. club sets off first gay riot. In C. Bull (Ed.), Witness to revolution: The Advocate reports on gay and lesbian politics, 1967-1999 (pp. 11-15). Los Angeles, CA: Alyson Books.

Levine, S., \& Thom, M. (2007). Bella Abzug: How one tough broad from the Bronx fought Jim Crow and Joe McCarthy, pissed off Jimmy Carter, battled for the rights of women and workers, rallied against war and for the planet, and shook up politics along the way: An oral history. New York, NY: Farrar, Straus, and Giroux.

Lewin, K. (1947). Frontiers in group dynamics. In D. Cartwright (Ed.). Field theory in social science. London, UK: Social Science Paperbacks.

Lewin, K. (1951). Field theory in social science. New York, NY: Harper. 
Lind, A. (2004). Legislating the family: Heterosexist bias in social welfare policy framework. Journal of Sociology and Social Welfare, 31, 21-35.

McShane, S. L., \& Von Glinow, M. A. (2008). Organizational behavior (4th ed.). Boston, MA: McGraw-Hill.

Mertus, J. (2007). The rejection of human rights framings: The case of LGBT advocacy in the U.S. Human Rights Quarterly, 29, 1036-1064. doi:10.1353/hrq.2007.0045

Monifa, A. (1998). Why I will remember Bella. Ms., 9, 80-81.

National Gay and Lesbian Taskforce. (2014). Historic victory: U.S. Senate passes Employment NonDiscrimination Act. Retrieved from http://www.thetaskforce.org/historic-victory-u-s-senatepasses-employment-non-discrimination-act/

Ogren, P. (1972, July 5). Bella at the baths. The Advocate, 89, 1.

Pelts, M. D. (2014). A look back at the Defense of Marriage Act: Why same-sex marriage is still relevant for social work. Affilia, 29, 237-247. doi:10.1177/0886109913519793

Potter, C. B. (2012). Paths to political citizenship: Gay rights, feminism, and the Carter presidency. Journal of Policy History, 24, 95-114. doi:10.1017/S089803061100039X

Privacy Act of 1974, 5 U.S.C. §552a. (1974). Retrieved from http://www.justice.gov/opcl/privacy-act1974

Rights struggles shifts to Capitol Hill. (1974, July 31). The Advocate, 143, 1.

Rodgers, K. (1998). Bella Abzug: A leader of vision and voice. Columbia Law Review, 98, 1145-1147.

Rudin, J. (2012) Halfway out: Why America's sexual minorities deserve better than the Employment Nondiscrimination Act. Journal of Workplace Rights 16, 337-351.

Russo, V. (1975, September 24). Bella, Bella, Bella! The Advocate, 173, 13.

Schulman, M. (2013, January). Generation LGBTQIA. New York Times. Retrieved from http://www.nytimes.com/2013/01/10/fashion/generation-lgbtqia.html?_r=0

Schultz, D. L. (2001). Going south: Jewish women in the civil rights movement. New York, NY: NYU Press.

Shepherd, C., Bell-Scott, P., Abzug, B., Lilly, K., Allison, D., \& Roddick, A. (1997). Yes, I am a feminist. $M s, 8,42-49$.

Sick no more. (1999). In C. Bull (Ed.), Witness to revolution: The Advocate reports on gay and lesbian politics, 1967-1999 (pp. 62-67). Los Angeles, CA: Alyson Books.

Sisneros, J., Stakeman, C., Joyner, M. C. \& Schmitz, S. L. (2008). Critical multicultural social work. Chicago, IL: Lyceum.

Steinem, G. (1996). Bella Abzug. Ms, 6, 62.

Styer, S. (1982). Exploring women's political careers through biographies. Social Studies, 73, 175177. doi:10.1080/00377996.1982.9956162

Vaid, U. (1995). Virtual equality: The mainstreaming of gay and lesbian liberation. New York, NY: Anchor Press.

Vitulli, E. (2010). A defining moment in civil rights history? The Employment Nondiscrimination Act, trans-inclusion, and homonormativity. Sexuality Research and Social Policy, 7, 155-167. doi:10.1007/s13178-010-0015-0 
Whisman, V. (2012). Queer by choice: Lesbians, gay men, and the politics of identity. New York, NY: Routledge.

White House. (2014). Remarks by the President at signing of executive order on LGBT workplace discrimination. Retrieved from http://www.whitehouse.gov/the-pressoffice/2014/07/21/remarks-president-signing-executive-order-lgbt-workplace-discrimination

The Journal of Social Change, sponsored by Walden University, welcomes manuscripts focusing on interdisciplinary research in social change that improves the human condition and moves people, groups, organizations, cultures, and society toward a more positive future.

Walden University Publishing: http://www.publishing.waldenu.edu 